\title{
Small-sized fish: the largest and most threatened portion of the megadiverse neotropical freshwater fish fauna
}

\author{
Ricardo M. C. Castro ${ }^{1 *(\mathbb{D}) \& \text { Carla N. M. Polaz }}{ }^{2}$ \\ ${ }^{1}$ Universidade de São Paulo, Faculdade de Filosofia, Ciências e Letras de Ribeirão Preto, Laboratório de \\ Ictiologia de Ribeirão Preto, Av. dos Bandeirantes, 3900, 14040-901, Ribeirão Preto, SP, Brasil. \\ ${ }^{2}$ Instituto Chico Mendes de Conservação da Biodiversidade, Centro Nacional de Pesquisa e Conservação \\ da Biodiversidade Aquática Continental, Rod. Pref. E. Nemésio Pereira de Godoy (SP 201) km 6.5, 64, \\ Pirassununga, SP, Brasil. \\ *Corresponding author: Ricardo M. C. Castro,e-mail: rmcastro@ffclrp.usp.br
}

CASTRO, R. M. C., POLAZ, C. N. M., Small-sized fish: the largest and most threatened portion of the megadiverse neotropical freshwater fish fauna. Biota Neotropica. 20(1): e20180683. http://dx.doi. org/10.1590/1676-0611-BN-2018-0683

\begin{abstract}
We introduce the work providing a synthetic description of the diversity and phyletic structure of freshwater fish in the Neotropical Region, especially emphasizing that of Brazil. This is accompanied by a discussion about environments of fish from small to medium sized to large, taking into account how it shaped their respective biologies/ecologies, as well as what they imply for their use by humans. We present, as figures, the results of our exploratory analysis of Brazilian Red Book of Threatened Species of Fauna (2018), focusing on the small-sized ones, with up to $15 \mathrm{~cm}$ of standard length. We continue to present the main human impacts in small fish environments, along with those suffered by medium to large fish environments, and then follow by their respective deleterious effects. Finally, we present a general synthesis, reinforcing the enormous importance of small fish conservation and their respective preferred environments, followed by our main conclusions, and possible conservation strategies. Keywords: Small fishes, Brazilian ichthyofauna, endangered fishes, conservation strategies, biodiversity policies.

\section{Peixes de pequeno porte: a porção maior e mais ameaçada da fauna megadiversa de peixes de água doce neotropicais}

Resumo: Iniciamos o trabalho fornecendo uma descrição sintética da diversidade e estrutura filética dos peixes de água doce da Região Neotropical, com ênfase naquela do Brasil, acompanhada de uma exposição sobre onde vivem os peixes de pequeno porte e os de porte médio a grande, levando em conta como isso moldou suas respectivas biologias/ecologias, e o que as mesmas implicam para seu uso pelos seres humanos. São apresentados, sob a forma de figuras, os resultados de uma análise exploratória dos dados sobre as 311 espécies de peixes ósseos de água doce contidos no Livro Vermelho da Fauna Brasileira Ameaçada de Extinção (2018), com ênfase naquelas de pequeno porte, com até $15 \mathrm{~cm}$ de comprimento padrão. Continuamos apresentando os principais impactos antrópicos nos ambientes de peixes de pequeno porte, juntamente com aqueles sofridos pelos ambientes de peixes de portes médio a grande, seguidos dos seus respectivos efeitos deletérios. Finalmente, concluímos com uma síntese geral, reforçando a enorme importância da conservação dos peixes de pequeno porte e seus ambientes preferenciais, e estratégias possíveis para conservação dos mesmos.

Palavras-chave: Peixes pequenos, ictiofauna brasileira, peixes ameaçados, estratégias de conservação, políticas de biodiversidade. 


\section{Introduction}

\section{Neotropical, South American and Brazilian ichthyofaunas}

The diversity and complexity of the ichthyofauna of the Neotropical inland waters is enormous, especially the South American ones, with a total number of species exceeding 7,000 and, thus, making it the richest species of continental fauna on the planet (Albert \& Reis, 2011). It is so rich that it contains one in five species of fish on the planet and approximately $10 \%$ of all living vertebrate species (Vari \& Malabarba, 1998).

In the Neotropical region, the most notable geological feature is the so-called South American Platform, containing the entire Amazon basin and adjacent areas, as well as the Brazilian and Guiana Shields, corresponding to approximately $62 \%$ of the South American continent, followed by the spectacular Cordillera of the Andes, approximately $7,000 \mathrm{~km}$ long, running along the west coast of the continent (Albert \& Reis 2011).

Using as an information source the last checklist of freshwater fishes of Central and South America (CLOFFSCA) (Reis et al. 2003), the most reliable completed publication of this type, its examination makes it possible to understand why the Neotropical freshwater is considered the richest and most diversified continental ichthyofauna on Earth, containing 71 families, several hundred genera and approximately 6,000 species.

According to Reis et al. (2003), the ichthyofaunas of Central and South American continental waters, with 4,475 species formally described up to the date of publication of the checklist, is dominated, both in terms of taxonomic diversity and biomass, by fishes belonging to the superorder Ostariophysi, series Otophysi, reaching approximately $73 \%$ of the described species, divided mostly among the orders Siluriformes (15 families and approximately $37 \%$ of the species) and Characiformes (14 families and approximately $33 \%$ of the species) and, secondarily, the order Gymnotiformes (five families and approximately 3\% of species); the remaining species are divided among the Cichlidae - of the order Perciformes (approximately 9\%), the order Cyprinodontiformes (approximately 12\%), both of the superorder Acanthopterygii, and a complex and varied remaining set (approximately $7 \%$ of the species total) formed by the species belonging to various taxonomic groups (families Potamotrygonidae, Lepidosirenidae, Osteoglossidae, Engraulidae, Clupeidae, Synbranchidae, Sciaenidae, Gobiidae, Nandidae, Belonidae, Tetraodontidae etc.). In a more recent review of the South American fish diversity, Reis et al. (2016) estimated the total number of freshwater fish species around 5.600, pointing to a final diversity between 8.000 and 9.000 species!

It is an ichthyofauna whose minimum age of the main lineages (orders Characiformes, Siluriformes and Gymnotiformes) is situated in the Cretaceous period, between 90 and 112 million years in the past (Lundberg et al., 1998). It occupies a vast area - mainly represented by the South American subcontinent. Because it is mainly composed of primary fresh water Otophysi fish, it is an ichthyofauna that has its evolutionary history closely linked to the geological history of the South American waterways.

In the special case of Brazil, a country whose 8.5 million $\mathrm{km}^{2}$ of area corresponds to almost half of the Neotropical region, the species richness of the continental water ichthyofauna, 3,148 species (ICMBio, 2018) is enormous (Machado, Drummond \& Paglia 2008, Albert \& Reis
2011). The simple examination of Figure 1 shows unmistakably and unequivocally how freshwater fish are fundamental in the diversity and conservation of Brazilian and neotropical vertebrate animals.

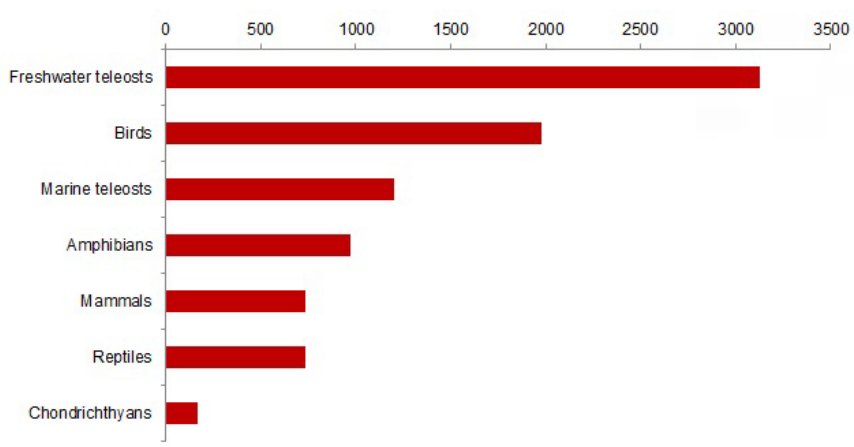

Figure 1. Species richness of Brazilian freshwater fishes among the Brazilian vertebrate fauna (five Myxini species and one lungfish species are not shown in graphic). Data from ICMBio (2018).

Although, on the one hand, the enormous absolute taxonomic diversity of the neotropical ichthyofauna and, especially, those of its South American and Brazilian fractions is generally known; however, on the other hand, the fact is that the absolute majority (around $70 \%$ ) of its component species (Reis et al., 2003) are small-sized, not reaching more than $15 \mathrm{~cm}$ of standard length (SL) when at adult size. This is not generally perceived by the general public or even by many professionals in the area of environmental conservation, despite the fact that this dominance of small-sized fish species has repeatedly been pointed out in the scientific literature for a good while (see Castro, 1999; Castro et al., 2005 and Albert, Bart \& Reis, 2011).

It is important to highlight here that, regardless of whether continental aquatic environments are primarily inhabited by small, medium or large-sized fish species, they have been systematically neglected in conservation issues (Abell et al. 2011), including in important global themes such as climate change. In a study conducted by Siqueira et al. (2009), in which the authors analyzed 263 articles dealing specifically with climate change and its effects on biodiversity, the authors found that in only $9 \%$ of the cases the continental aquatic environments were considered, compared to $75 \%$ for terrestrial environments, although projections of the impacts of climate change on aquatic environments are equally drastic (eg Goldman et al. 2012).

This dominance of the small-sized species in the Neotropical ichthyofauna, especially the South American one, together with their very low perception by the majority of people, entails a whole series of consequences, in our opinion mostly deleterious, for the knowledge, conservation and use of this ichthyofauna, as we will show next in this paper.

\section{Material and Methods}

Since this work focuses on the diversity of small-sized fish in the Neotropical region, especially that of Brazil, we think that it is important to first define what we are calling "fish diversity" and, afterwards, what we consider small, medium and large-sized fish.

The diversity we are talking about here is equal to the diversity expressed in the number of fish species recognized for an area, biome, 
or habitat type. Regarding the size of fish species, we follow Castro (1999) and Castro et al. (2005) and consider those with up to $15 \mathrm{~cm}$ of standard length (SL) as small-sized Figures 2 and 3). This is equal to the distance between the tip of the fish's snout and the base of the rays of its caudal fin when at adult size. As an upper limit of size for the socalled medium-sized species, we chose $45 \mathrm{~cm}$ of standard length (SL) when at adult size. This is a value very close to the maximum standard length of $46 \mathrm{~cm}$ found by Castro \& Vari (2004: 81) for all species of the genus Prochilodus measured by the cited authors (Figure 4). It is the most specious and widely distributed of the family Prochilodontidae, one of the most important, if not the most, freshwater fish family in the commercial and self-consumption fishing in South America (Castro \& Vari, 2003). Obviously, we consider large-sized all species of freshwater fish to be more than $45 \mathrm{~cm}$ in standard length when at adult size.

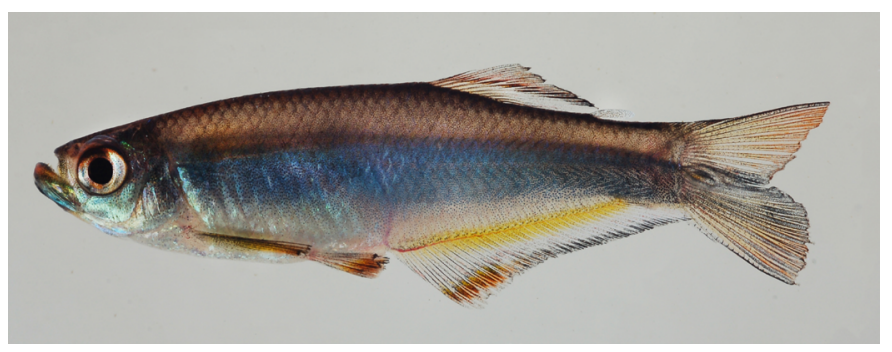

Figure 2. An adult male (SL $5.2 \mathrm{~cm}$ ) of the glandulocaudine small-sized characid fish species Mimagoniates microlepis, from southeastern Brazil. Photo RMC Castro.

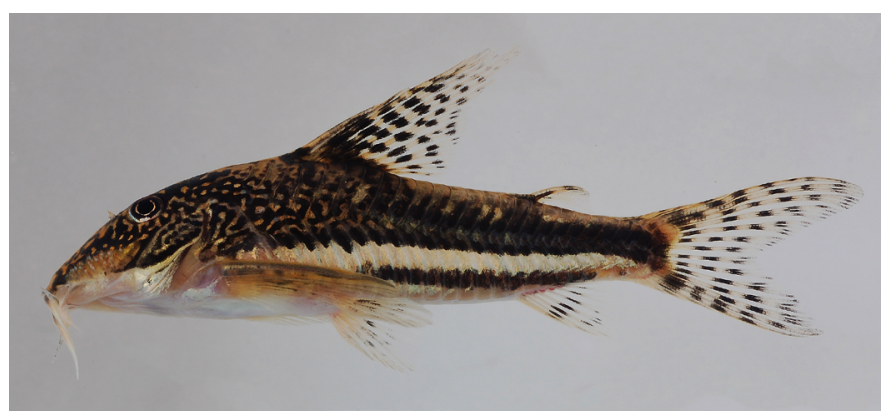

Figure 3. An adult male (SL $6.2 \mathrm{~cm}$ ) of the small-sized callichthyid armored catfish species Scleromystax barbatus from southeastern Brazil. Photo RMC Castro.

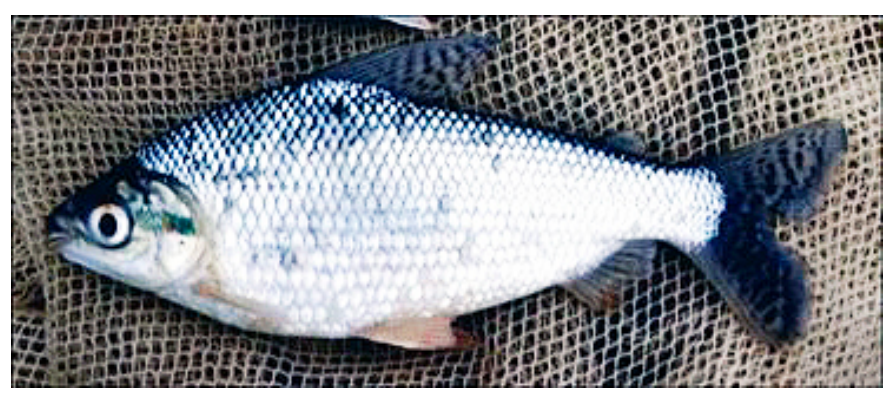

Figure 4. An adult of the flannel mouth prochilodontid medium-sized fish species Prochilodus nigricans (cf. Castro \& Vari 2004), widely distributed in the Amazon basin, northern Brazil. Photo RP Vari.
Since Brazil is the fifth largest country in the world by area, occupying near $45 \%$ of the Neotropical Region's 19 million $\mathrm{km}^{2}$, we believe it is therefore an excellent example case for the region with regards to the evaluation of the conservation status of its ichthyofauna, and particularly the small-sized species. For this evaluation, we will mainly use data that have been extracted and systematized from the Brazilian Red Book of Threatened Species of Fauna (Chapter VI: Fishes), published by the Chico Mendes Institute for Conservation of Biodiversity - ICMBio (2018). We excluded the marine fish from our evaluation because our focus here is on freshwater fish, especially the small-sized ones.

The preparation of the most recent edition of the Brazilian Red Book resulted from a process known as Red List Assessment (RLA) of Brazilian Wildlife, attributed to the ICMBio by the Ministry of Environment. In the RLA process, 12,254 animal species were evaluated individually, and the majority of them $(8,922)$ were vertebrates, encompassing all described Brazilian vertebrate species in the country until the middle of 2014. To evaluate the 3,148 Brazilian continental fish species known to date, 11 workshops were carried out with the participation of about 170 ichthyologists in total, providing scientific data on taxonomy, biology, ecology, and threats to each species. After organizing this information in individual species assessment sheets, the quantitative criteria adopted by the International Union for Conservation of Nature (IUCN) were applied to determine one of the 11 IUCN categories. Three of these 11 categories are considered at risk of extinction, from the highest to the lowest threat level: CR - Critically Endangered; EN - Endangered; and VU - Vulnerable.

Based on Castro (1999), we consider here that the term stream refers to those parts of any fluvial system, ideally little or not altered by deleterious anthropic action, where, within the River Continuum Concept (Vannote et al., 1980; Peres Neto et al., 1994), local autotrophic primary production is low due to the presence of riparian vegetation, partially or totally blocking the direct incidence of sunlight. In addition, the lotic community is predominantly heterotrophic, depending heavily on imported allochthonous organic material for its subsistence. In general, larger bodies of water have greater insolation that allows for the existence of algae and macrophytes and leads to a relatively higher local primary production, making the lotic community less dependent on the importation of organic matter for their subsistence. The point where a creek changes from heterotrophic to autotrophic depends primarily on the level of shading, and hence the presence, density, and position of riparian vegetation, which in turn, depend on the dominant vegetation type in the area, latitude, altitude, and physical structure of the stream. However, generally speaking, this heterotrophic condition is generally found in rivers equal to or less than order level four, having relatively small physical dimensions, dense riparian vegetation, relatively strong current, irregular bottom composed predominantly of coarse sand, gravel, and rocks, transparent and cold water, alternating pools and rapids, and a sizeable amount of decaying foliage, twigs, and branches accumulating at the bottom of the pools and backwaters (Figure 5).

We follow Costa $(2002,2009)$ in his definitions of permanent or temporary ponds and marshes, which are swallow water bodies, with 10 to $100 \mathrm{~cm}$ depth, in relatively level terrain, that are formed either by 


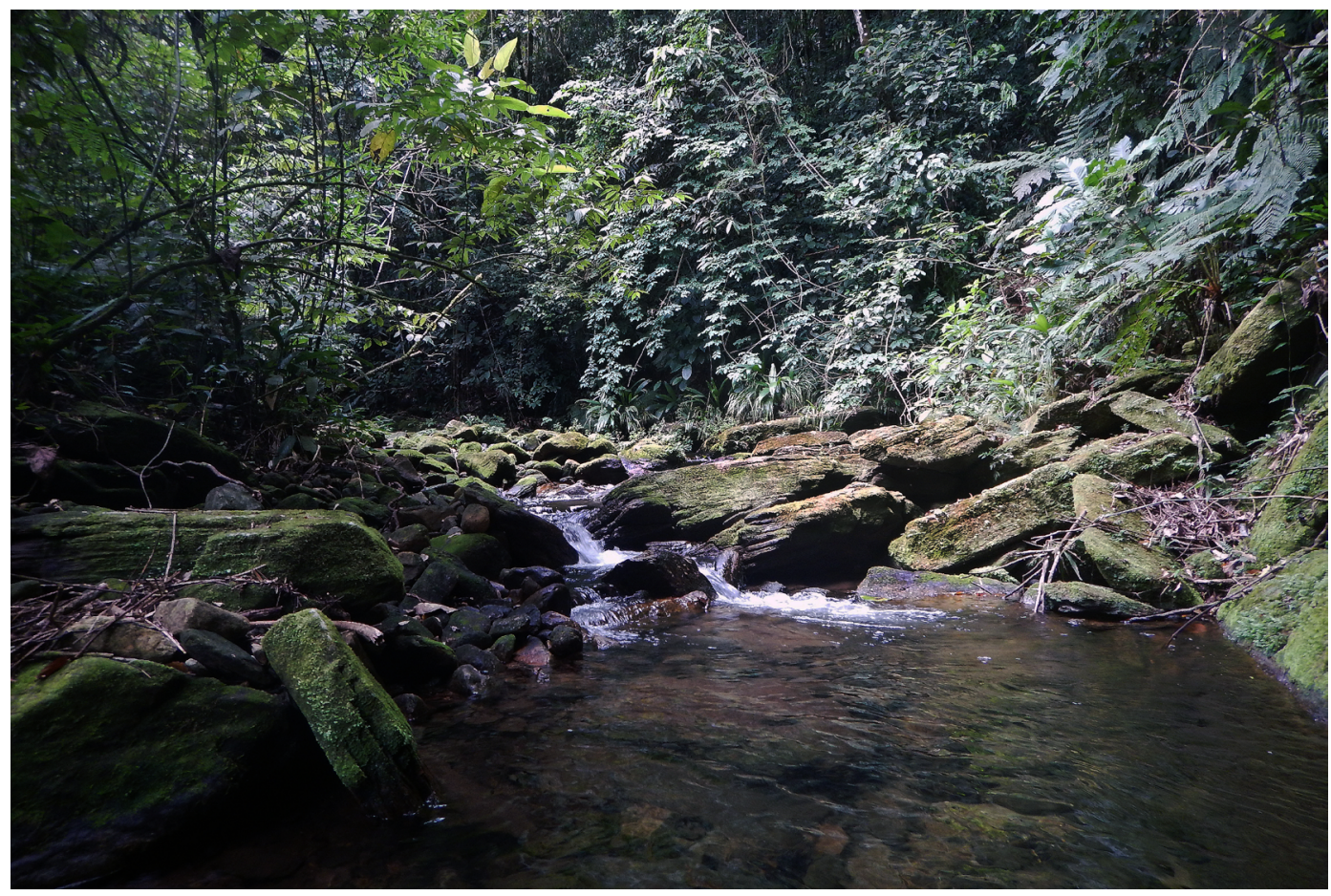

Figure 5. Stream draining the foothills of the Serra do Mar in southeastern Brazil. Photo RMC Castro.

the accumulation of rainwater in depressions or by the usually seasonal overflow of larger water courses. These water bodies are partially or completely cut of from nearby rivers and lakes, with very distinct physical and chemical attributes depending on the vegetation where they are located (Figure 6).

\section{Results}

\section{Small-sized fish: their diversity, habitats, biology and human use}

According to the criterion used, small-sized fish species are the ones of $15 \mathrm{~cm}$ or less of standard length (SL) when at adult size, which correspond to approximately $70 \%$ of the diversity in freshwater fish species of the Neotropical region (Reis et al., 2003). Of the 3,148 evaluated species of freshwater fish, 311 (approximately 10\%) formally described species were classified into one of three threat categories (Figure 7). Of these, 253 species, equivalent to $81 \%$ of the total endangered species of freshwater fish, are what we call small-sized fish, being $15 \mathrm{~cm}$ or less in standard length when at adult size (Figure 8).

Unlike the medium to large-sized fish species, which are almost always inhabitants of major river channels, species of small-sized Neotropical freshwater fish, including those considered threatened, generally inhabit either ponds and marshes - temporary or otherwise-, as well as streams (Figure 9).

Among the 3,148 spp. listed in the most recent edition of the Brazilian Red Book (ICMBio, 2018), 252 species of fish (approximately $8 \%$ of the total), all of which small-sized, belong to the order Cyprinodontiformes (Figure 10) and mostly to the kilifish Rivulidae family (Figure 11), which species inhabit, permanently or temporarily, ponds and marshes. Among the Rivulidae, most of its approximately 250 Brazilian species (ICMBio, 2018) belong to a group known as "annual fishes", a total of 158 species that receive this name due to always completing their entire life cycle in temporary aquatic environments that only exist as adults for brief periods of the year (Figures 6 and 12). In drought periods, only their eggs remain in the substrate and in diapause, in almost complete metabolic suspension, waiting for the next rains to give rise to fish that grow very fast to reach sexual maturity and spawning before the subsequent dry season. They are so adapted to this type of temporary environment, as they are not found in other types of non-temporary aquatic environments (Costa, 1995, 2002, 2009). This a life-cycle characteristic that seems to pose serious problems for their conservation, since, of the 311 species of Brazil's freshwater fishes threatened to some degree, about $40 \%$ are Rivulidae! Of these, approximately $82 \%$ are annual fish (for a brief review of the Brazilian killifish extinction risk see Volcan \& Lanés, 2018).

When analyzing the distribution of endangered species of fish, regardless of size, in Brazilian biomes, it was observed that the Atlantic Forest and Cerrado concentrate the largest number of threatened fishes, respectively presenting 35 and $23 \%$ of the total endangered species at the national level (Figure 13). If restricted to the smallsized threatened fish, the percentages remain close: 36 and $26 \%$, respectively. The occurrence of the largest numbers of threatened fishes in the Atlantic Forest and Cerrado are to be expected, since as has been said previously, fish species (Figure 14) that inhabit more modestly sized aquatic environments, such as streams, ponds, and marshes have almost invariably restricted geographic distributions with and are generally very dependent on the existence of riparian vegetation for their food, shelter, and breeding sites (Costa, 1995, 2002, 2009, and Castro, 1999; Castro et al., 2005). 


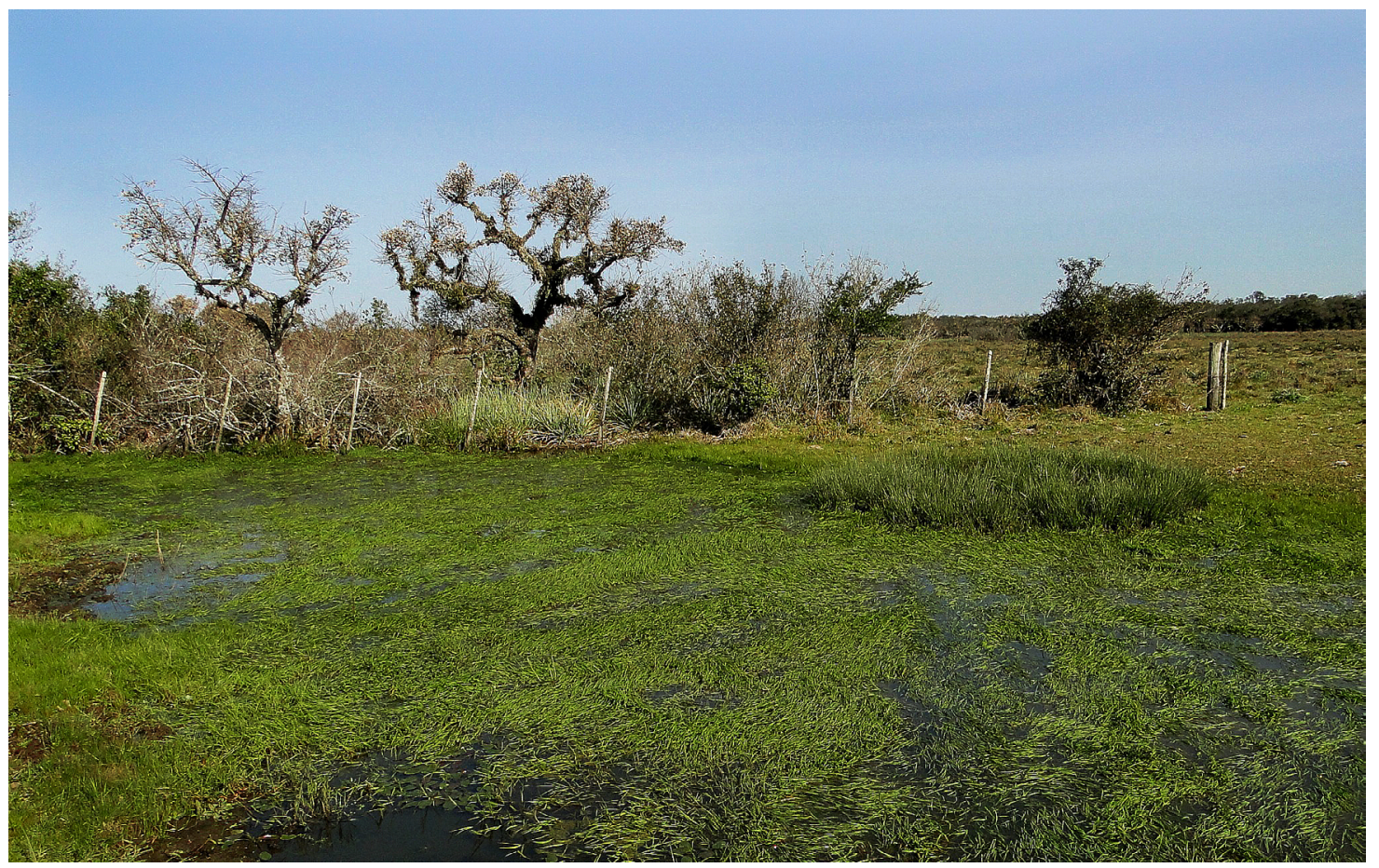

Figure 6. Typical temporary pond in southern Brazil where annual rivulids live. Photo MV Volcan.

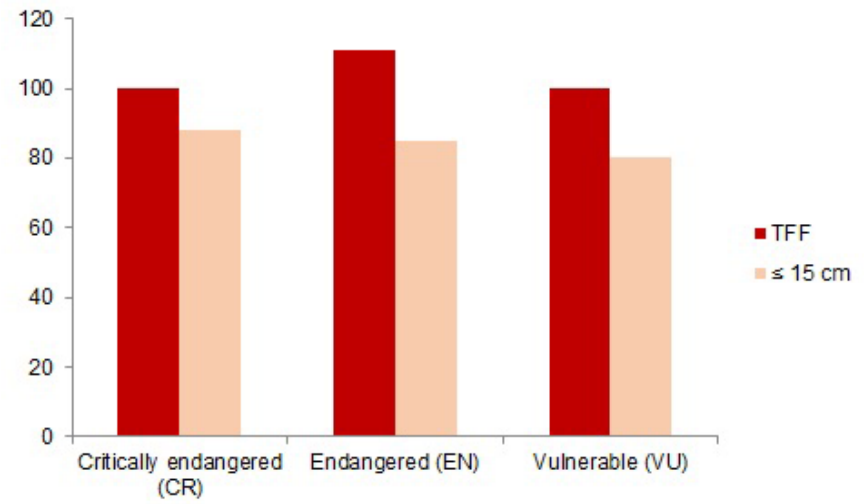

Figure 7. Categories at risk of extinction, according to the IUCN, of all the 311 Threatened Freshwater Fishes (TFF) listed in the Brazilian Red Book (ICMBio, 2018), as compared to only small-sized ones.

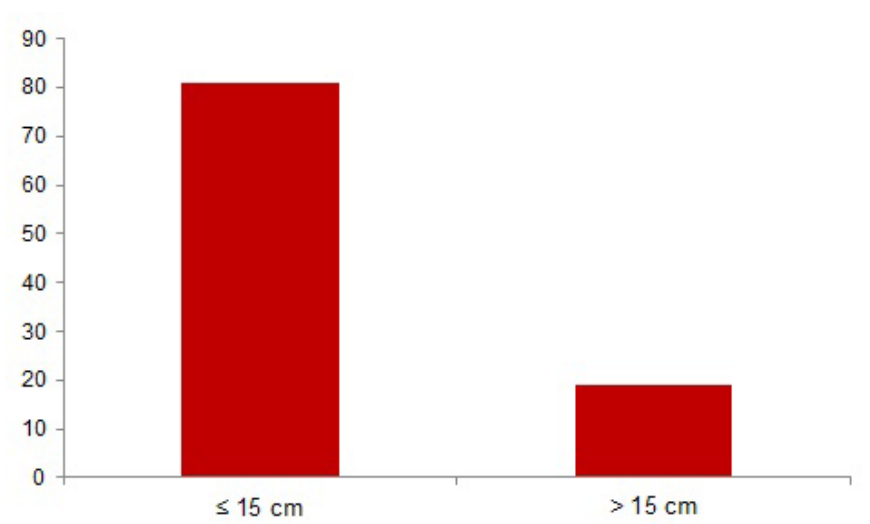

Figure 8. Size ranges (\%) of the Threatened Freshwater Fishes (TFF) in the Brazilian Red Book (ICMBio, 2018): below or equal to $15 \mathrm{~cm}$ (SL) = smallsized; above $15 \mathrm{~cm}(\mathrm{SL})=$ medium or large-sized.

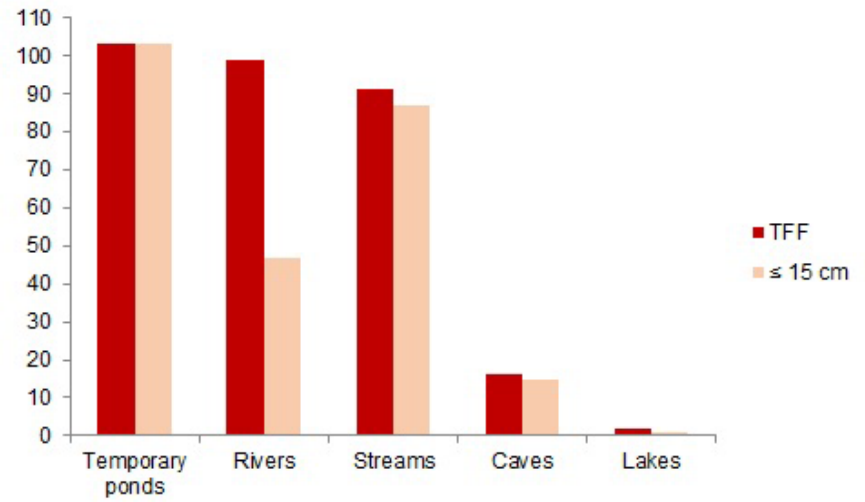

Figure 9. Types of environment in which the totality of the 311 Threatened Freshwater Fish (TFF) species listed in the Brazilian Red Book (ICMBio, 2018) preferably live, as compared to only small-sized ones.

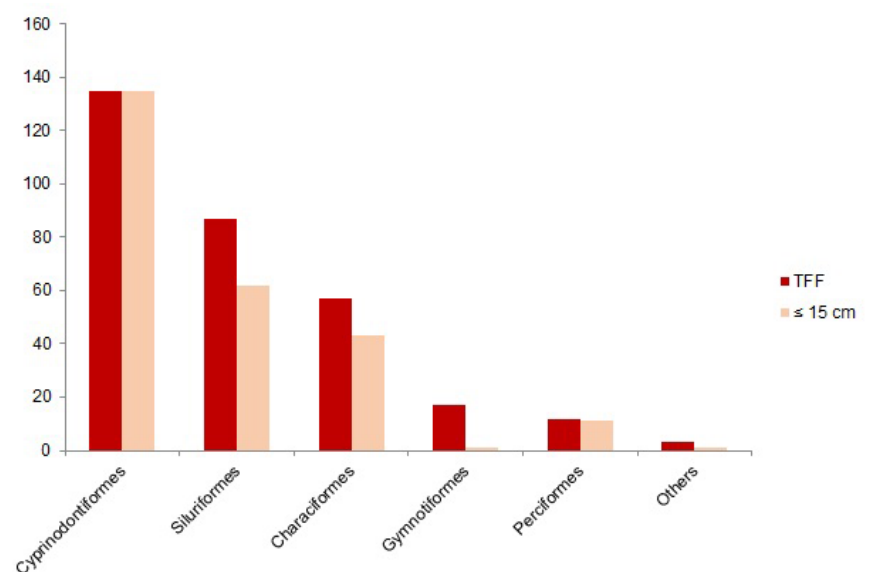

Figure 10. Distribution of the all 311 species of Threatened Freshwater Fishes (TFF) listed in the Brazilian Red Book (ICMBio, 2018) among the fish orders, in comparison with only the small-sized ones. 


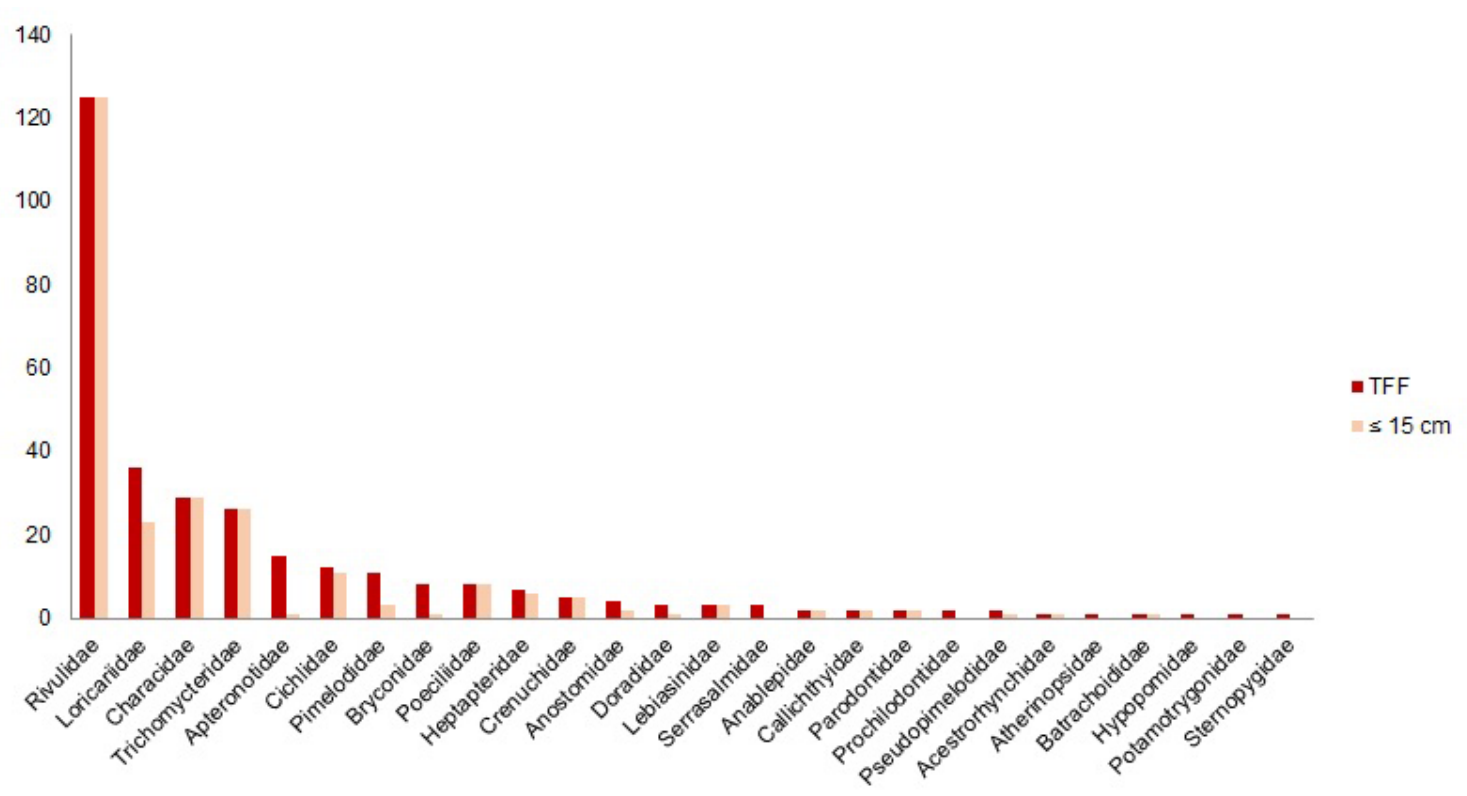

Figure 11. Distribution of all the 311 endangered fish species of Threatened Freshwater Fishes (TFF) listed in the Brazilian Red Book (ICMBio, 2018) among fish families, in comparison with only the small-sized ones.

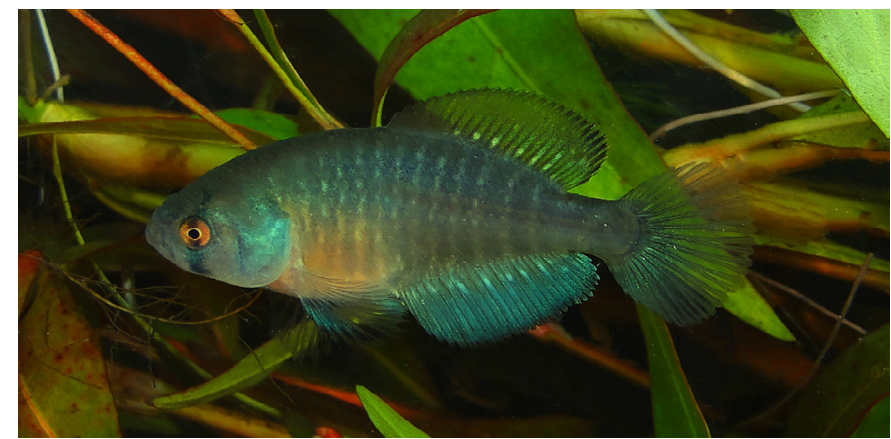

Figure 12. An adult male $(\mathrm{SL}=3.5 \mathrm{~cm})$ of the annual rivulid Austrolebias univentripinnis, a small-sized inhabitant of temporary marshes and ponds in southern Brazil. Photo MV Volcan.

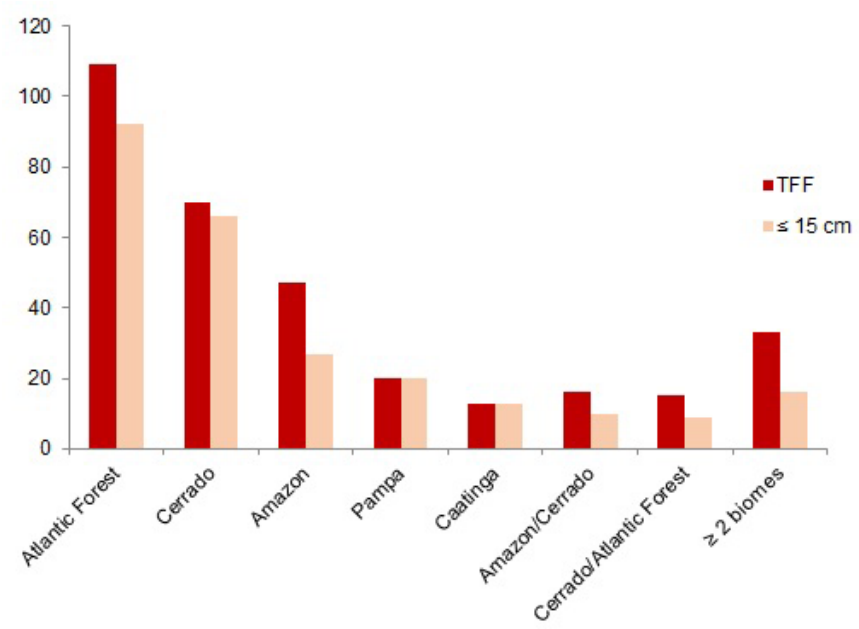

Figure 13. Distribution among the Brazilian biomes of the 311 species of Threatened Freshwater Fishes (TFF) listed in the Brazilian Red Book (ICMBio 2018), in comparison with only the small-sized ones.

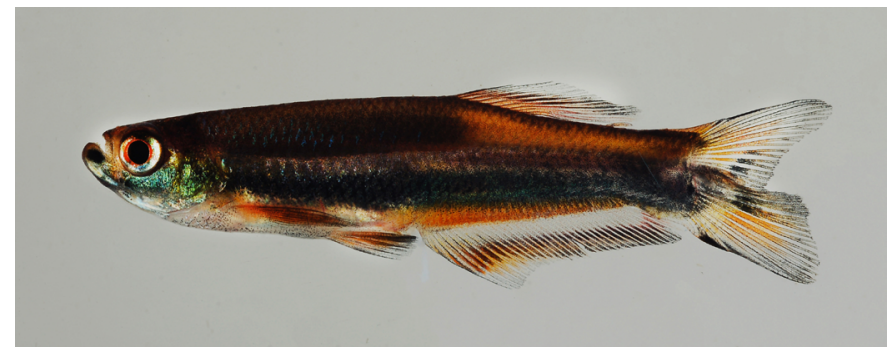

Figure 14. An adult male (SL $3.2 \mathrm{~cm}$ ) of the glandulocaudine small-sized characid fish species Mimagoniates lateralis, inhabitant of black acid water streams, marshes, and ponds of the Atlantic Forest in southeastern Brazil. Photo RMC Castro.

\section{Medium to large-sized fish: their diversity, habitats, biology and human use}

According to the criterion adopted in this work, fish species more than 15 and up to $45 \mathrm{~cm}$ of standard length (SL) when at adult size are considered as medium-sized, and fish species more than $45 \mathrm{~cm}$ of standard length (SL) when at adult size are considered as large-sized. Together, the medium and large-sized species make up about $30 \%$ of the diversity in freshwater fish species of the Neotropical region (Reis et al., 2003).

Most of these medium and large-sized species inhabit the main river channels; in this case, rivers of usually greater than fourth order (cf. Strahler, 1957), such as the Curimbatás, Sábalos, Bocachicos (Prochilodus spp.) (see Figure 4); dourados, dorados, pirayús (Salminus spp.) (Figures 8 and 9), piaparas, bogas (Leporinus spp.); pintados, suruvis, pintadillos (Pseudoplatystoma spp.); jaraquis, zapoaras (Semaprochilodus spp.); douradas, doradas (Brachyplatystoma rousseauxii) (Figures 10 and 11); piraíbas, valentons, lecheros (Brachyplatystoma filamentosum); pacus-caranha (Piaractus mesopotamicus); jaús, amarillos (Zungaro spp.) etc. These are usually of importance in commercial, sport, and sustenance fishing. 
The physicochemical composition of the waters of the main river channels is always fluctuating in time and space because these waters are the final destination of the drainage of areas that can reach millions of $\mathrm{km}^{2}$ in the case of the great South American basins, such as the Amazon and that of the Plata-Uruguay-Parana-Paraguay river system, and these drain 3.2 million $\mathrm{km}^{2}$ (Lowe-McConnell, 1987, 1999). Generally speaking, the main channel inhabitant species (see Figures 15 and 16) have great tolerance to natural environmental variations.

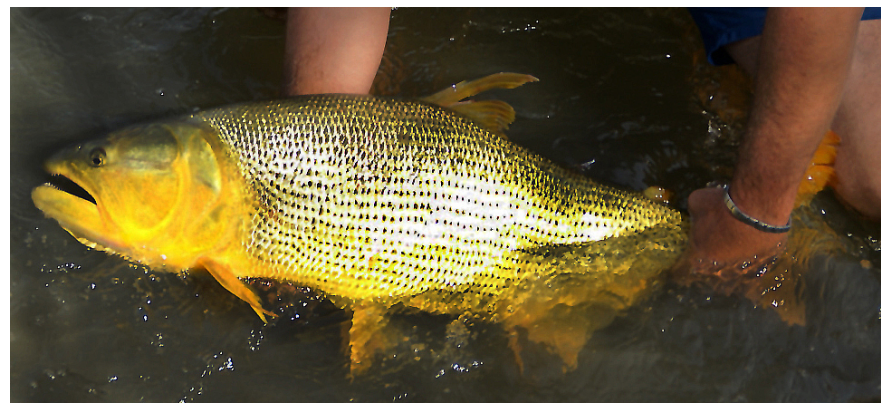

Figure 15. A beautiful adult specimen of "dourado", of the large-sized bryconid species Salminus brasiliensis, in the Mogi Guaçu river, of the upper Paraná river basin, southeastern Brazil. Photo L Milano.

In addition, such species tend to have very extensive geographic distributions, small morphological, and genetic variability because they are generally migratory. They are often present in almost the totality of a large river basin, such as, for example, Prochilodus nigricans Agassiz, 1829 (see Figure 52, geographic distribution in the gigantic Amazon basin in Castro \& Vari, 2004).
Most probably due to their large geographic distribution, comparatively high ecological tolerance and usually large biomass, medium and large-sized fish species are only 58 of the 311 endangered Brazilian continental ones (see Figure 8), most of which inhabit major medium to large sized rivers (see Figures 17 and 18). Nevertheless, the most of them are highly valuable and interesting to us and, therefore, are heavily targeted for different types of human use, being the most obvious of them fishing in its different modalities. Whether for consumption, sport, or commercialization, fish that present greater biomass naturally become more attractive targets when considering the fishing activity. On the other hand, fish that form large schools, as is the case for almost all Prochilodontidae species, even those with smaller individual weight, are equally attractive because of their increased catchability.

Also, in terms of fish farming, larger fish are far more advantageous for cultivation than small fish, with the exception of some Brazilian species of characid lambaris (Astyanax spp.), which are highly prized by fish farmers and are mainly sold as live bait for larger predator fishes.

\section{Discussion}

\section{Main impacts on preferential habitats of small-sized fish}

The first major impact on small-sized fish is the lack of knowledge about them. Yes, despite this sounding as an argument worthy of the category "biological truisms", in the case of a megadiverse country like Brazil for which much of its biodiversity not even described yet, we do not know many aspects of the biology and ecology of these vertebrates (imagine in invertebrate's case!). If aspects as basal as

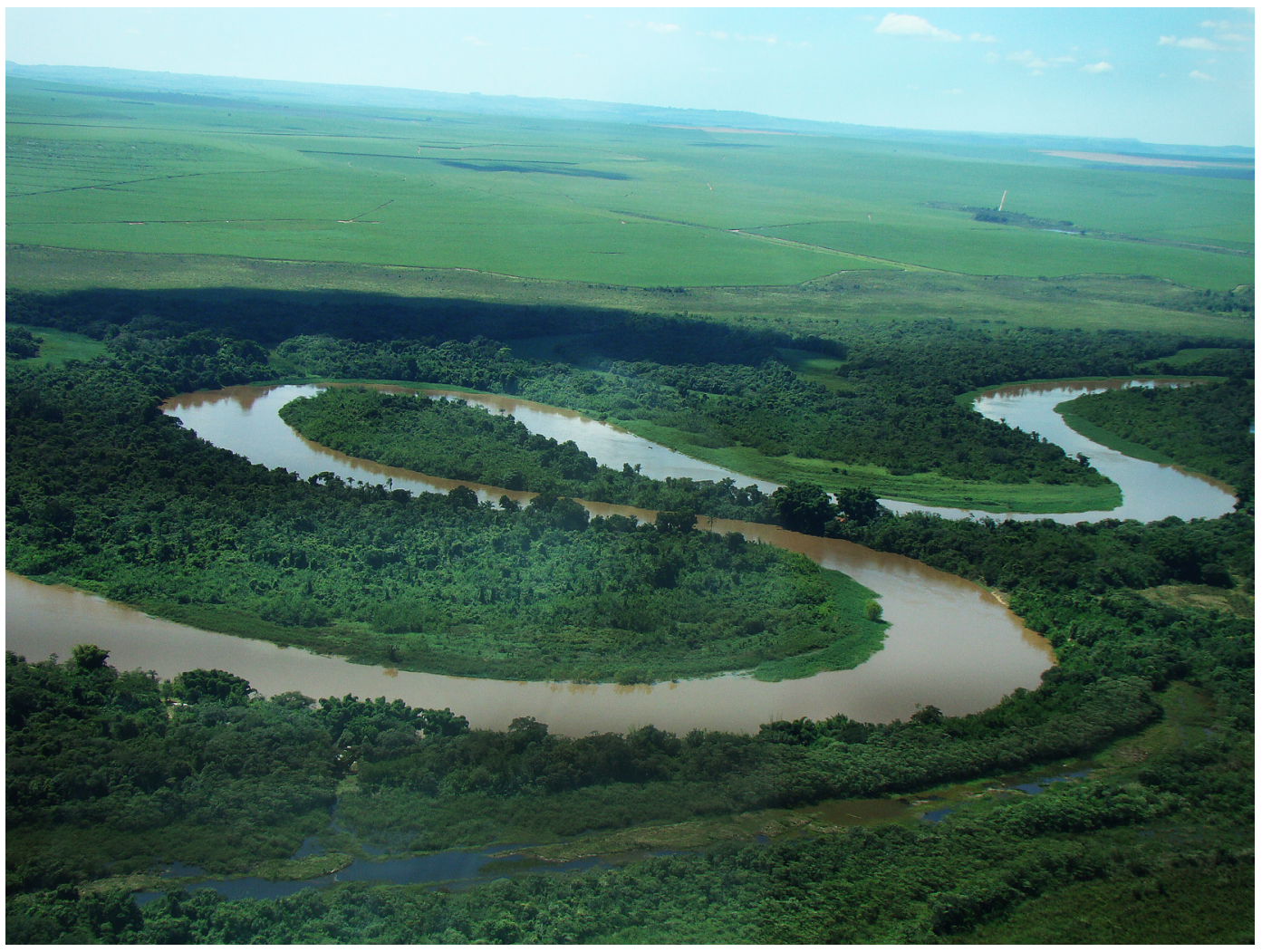

Figure 16. Main channel of the Mogi Guaçu river, upper Paraná river basin, in southeastern Brazil. Photo S Antoninni. 


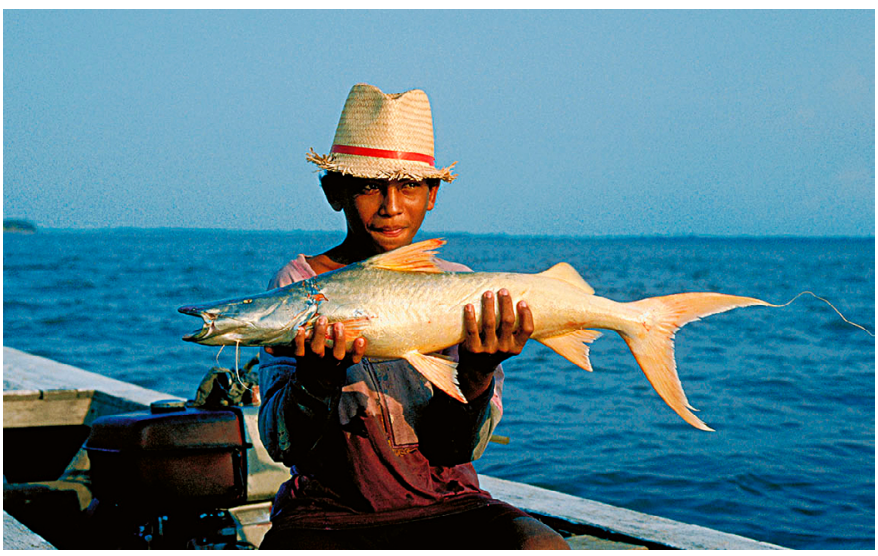

Figure 17. A specimen of the large-sized pimelodid goliath catfish species Brachyplatystoma rousseauxii from the main channels of the great Amazonian rivers in northern Brazil. Photo M Goulding.

these are unknown, it is very difficult to analyze how the different anthropic impacts affect or reduce the small-sized fish populations. This type of analysis is of paramount importance for the assessment of their conservation status. We probably have a grossly underestimated number of endangered fish species just because we ignore how their respective threat triggers work.

Our conservation assessments are still very much based on the perception of "scorched earth". To construct a didactic comparison, when the "house" or the habitat of a species is destroyed, such a severe impact is imposed upon it that, from this point on, little or nothing can be done to recover it. This is the case of some endemic species of small-sized Amazonian suckermouth armored loricariid catfishes, such Hypancistrus zebra and Scobinancistrus aureatus, especiallly threatened by the construction of large hydroelectric power plants such as Belo Monte UHE in the Xingu River. Undoubtedly, these species are endangered and dependent on immediate conservation measures, such as the ones contained in the Brazilian Ministry of the Environment
(MMA) Ministerial Order No. 130/2018. A similar case occurs with the annual fish species of the Rivulidae family, which contains the largest number of currently endangered fish species (125 spp.). This is because almost all inhabit temporary marshes and ponds, highly susceptible from minor to major anthropogenic interventions of different natures, such as: landfilling, irrigation, animal watering, and conversion of the natural environment to agricultural ones, among others (Calhoun et al., 2017; Costa, 2002).

In studies involving streams belonging to different biomes and geographic regions, Castro (1999) detected and was later corroborated by several authors that concluded that there is absolute dominance of small fish species in the South American stream ichthyofauna (e.g. Castro \& Casatti, 1997; Castro et. al, 2003; Castro et al. 2004; Castro et al. 2005; Langeani 2007; Apone et al. 2008; Esguícero \& Arcifa 2011, Casatti et al. 2013; Fagundes et al. 2015). We also cite here that one of the present authors (RMCC) and collaborators (Castro et. al, 2003; Castro et al., 2004, Castro et al., 2005), when analyzing the structure and composition of the ichthyofauna of 59 stretches of streams 100 meters long (practically all of them of river order equal to or less than three - cf. Strahler, 1957) and all belonging to the Upper Parana River system, achieved almost complete removal through a combination of electric fishing, small handheld seines and hoop nets to collect 14,942 specimens of fish belonging six orders, 22 families, 59 genera, and 92 species with a total biomass of $59.9 \mathrm{~kg}$. Of the 92 collected species, 66 (72\%) are less than $15 \mathrm{~cm}$ in standard length (SL) when at adult size. Additionally, only 13 of the 92 species collected in the three studies $(14 \%)$ were specimens larger than $15 \mathrm{~cm}$ of standard length.

In the case of small-sized fish inhabiting streams, generally speaking, the main impacts are undoubtedly primarily due to the suppression or reduction of original vegetation cover due to agriculture, forestry, and, to a lesser extent, urban expansion (for a comparative study of the effects on fishes of the differential riparian vegetation suppression on 15 streams stretches see Casatti et al., 2012). When this occurs, soil erosion and consequent silting of the environments also occurs,

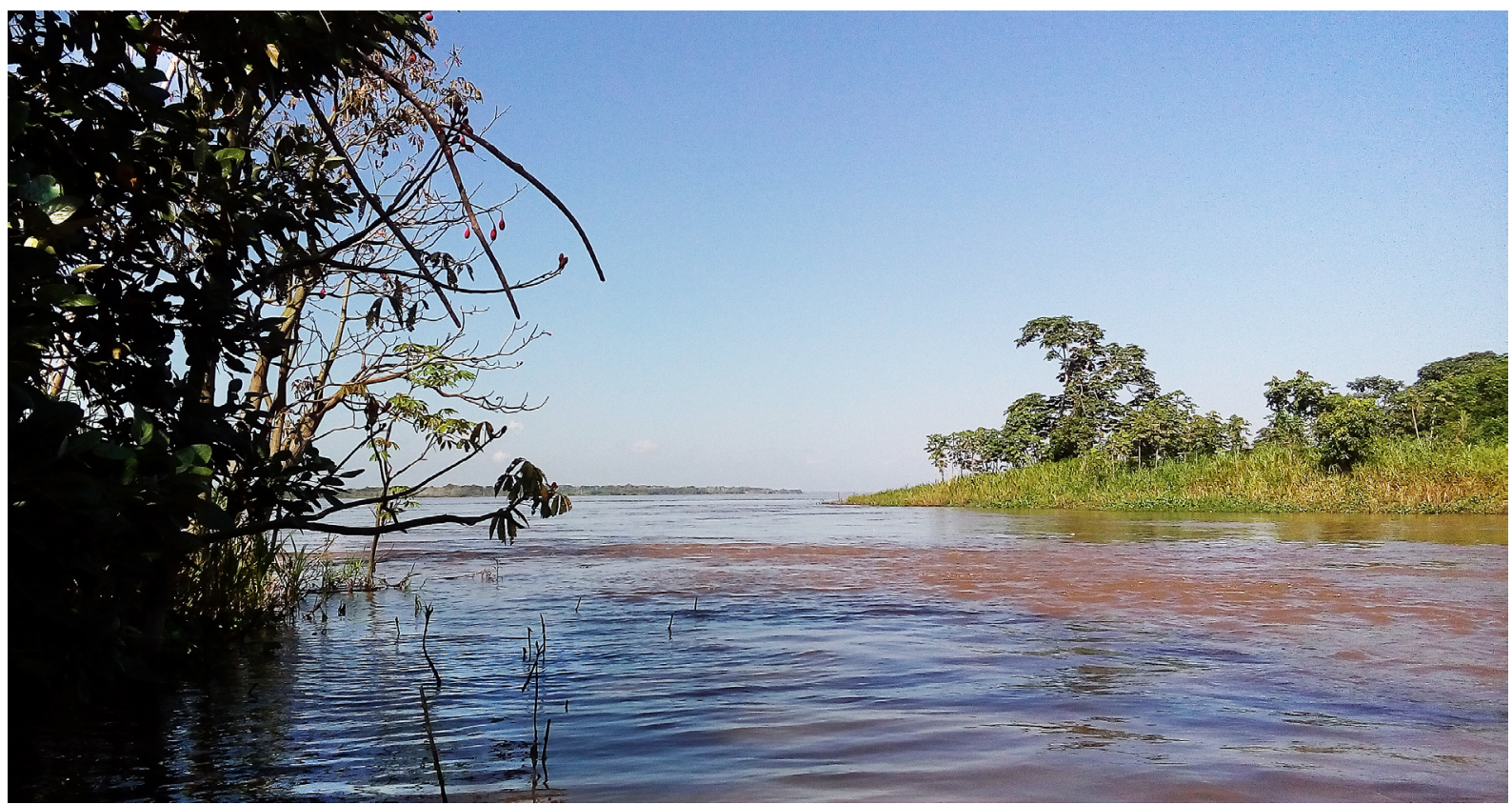

Figure 18. Channel of the Amazon river northern Brazil. Photo CNM Polaz. 
accompanied by often drastic changes in the physical and chemical characteristics of the water, levels of direct insolation, and water flow. There are also notable changes in food supply, since riparian vegetation is often crucial for the maintenance, both outside and inside the water, of arthropod populations, as it is the main component of the diet of stream fishes as a whole (see Castro et al., 2005 and Menezes et al., 2007). In addition, waterproofing of runoff surfaces, diffuse pollution, domestic or industrial sewage, and the introduction of exotic species, mainly related to aquarium trade (Magalhães and Jacobi, 2013a), also tend to impact fish and stream environments, albeit to a much smaller and more geographically restricted extent.

The fact that the small-sized fish species discussed here, in general, do not present high biomasses at either at the individual or at the collective levels, makes them not as interesting as targets of commercial, sustenance, or sports fishing. Likewise, they are also not usually used for fish farming for food purposes. At the present date, the main commercial use of small-sized freshwater fish species is in the aquarium trade, and particularly in Brazil, several species that until recently came exclusively from catches in their natural environments, such as the Amazonian neon tetras (Paracheirodon spp.) (Ribeiro et al., 2008), currently come from captivity in an increasing rate. They are often bred and raised abroad in countries, such as Singapore and Thailand (Ribeiro, 2008), which also supply the Brazilian domestic market.

Another threat is the use of some small-sized fish species, such as the "tetras" or lambaris Astyanax spp. and the naked-back knifefishes or tuviras Gymnotus spp., in various regions of Brazil and South America as live baits for predatory fish species targeted by sport fishermen (Moraes and Espinoza, 2001), such as dourados, pintados, sorubins and tucunarés (Salminus spp. Pseudoplatystoma spp. and Cichla spp., respectively).

On the other hand, when threats to the small-sized fish are not as obvious or indirect, conservation opportunities can slip through our fingers. Fighting an "invisible" enemy is a complex task that demands time, investment, and human resources, a condition rarely available in the world of conservation. It is, therefore, a relatively common methodological conservation artifact to resort to regionalized approaches for impact analysis, usually utilizing biomes.

This is congruent, and not randomly, with the so-called global hotspots of biodiversity. Of the 25 ecosystems listed by Myers et al. (2000), two occur in Brazil and are precisely the Atlantic Forest and the Cerrado (Brazilian savannah), taking into account the two main criteria used by Myers et al. (2000), which are increasing rates of habitat loss and high rates of endemism. In addition, hyperdiverse tropical ecosystems, that hold the largest share of global biodiversity, are daily in confrontation with the unbearable effects of many severe environmental stressors, such as deforestation, overexploitation and climate change (Barlow et al., 2018).

\section{Main impacts on the preferred habitats of medium to large-sized fish}

Impact is understood here to mean any phenomena or activities of anthropic or natural origin that affect the life cycle of the species at some level stages or processes. However, in the context of this work, we will address those impacts caused by man on fish.

It is intuitive to think that, considering the size limits between small and large-sized fish, different impacts will have different effects on their populations (see Figure 8). However, evaluating the magnitude and intensity of an impact on a linear relationship between fish size and "size" of a given enterprise, for example, can lead to serious misunderstandings, even though it is tempting. In general, large-sized fish are associated with migration, which may be larger or smaller in distance, depending on the starting point of the fish and the final destination of its route. For example, it has recently been confirmed that the pimelodid goliath catfish Brachyplatystoma rousseauxii Castelnau, 1855 (see Figures 17 and 18) is the freshwater fish with the longest migratory route known. Starting at the Andes, it travels at least $5,786 \mathrm{~km}$, and spawns in the general region of the Amazon River mouth in the state of Pará in northern Brazil (Barthem et al., 2017).

Returning to the tempting idea of correlating sizes, the interruption of migratory routes may be due to undertakings or activities that are not necessarily considered "large". Partial or total interruptions of these routes can be caused by relatively modest structures that are able to block water courses. This is the case of artificial dams or small hydropower plants (PCHs). Looking at the small fishes, as far as is known, a much smaller proportion of this category makes significant migrations - that is, those considered long distances (hundreds of kilometers). However, there is complete ignorance of the real negative impacts of river damming on small-sized fish species in Brazil, since they are not even considered in environmental licensing studies, which have traditionally been focused only in monitoring medium or large-sized migratory fish.

Other impacts that may be very relevant for the reduction of fish species populations, in general and regardless of their size, include: the release of domestic and industrial effluents in natura; irregular water abstraction for urban, industrial, or agricultural uses; mining, in particular for the extraction of sand form the riverbeds; rectification of the river channels; and the aforementioned river damming. All these impacts are, in fact, drastic interferences in the aquatic environment, which affect far more freshwater fish populations than the fishing itself (ICMBio, 2018).

For the endangered species of freshwater fish in Brazil, the Brazilian Red Book (ICMBio, 2018) identifies the main threat vectors as agriculture (often in a massive scale) and hydroelectric energy generation (the second case certainly affecting more medium and large-sized fish). It is interesting to note that, for freshwater fish, fishing and capture was considered only the fifth vector in a diminishing level scale, showing that fishing itself has very specific effects and cannot be considered a broad-spectrum threat.

\section{Conservation strategies for small-sized fish}

The act of planning requires various levels. Each level of planning per se, therefore, will require the adoption of different strategies. Likewise, planning for conservation will require different strategies from the planner, according to the target to be conserved and the scale of the strategic effect that one wants to achieve. Keeping a species in isolation is very different from preserving a species community. Furthermore, conserving the same species in different biomes can also be completely distinct, since the extrinsic factors inherent to the maintenance of that species in environment A may require strategies quite different from those required in environment $\mathrm{B}$. This forces the planner to obtain prior knowledge of both the target species and its environment and, then, propose the best conservation strategy accordingly. 
There are globally well known and widespread strategies. The main ones are the conservation of species through the protection of their territories, the so-called "protected areas". In Brazil, for example, this is undoubtedly the strategy that underlies and inaugurates the National System of Conservation Units (SNUC), which currently houses 335 Conservation Units at the federal level and corresponds to approximately $10 \%$ of the Brazilian territory (ICMBio - electronic portal). However, it is widely known that Conservation Units, with the exception of marine ones that have little representativeness in the total of effectively protected Brazilian area, do not privilege aquatic environments and, consequently, the species that live there. It is concluded from this discussion, already well established in the literature on aquatic conservation, that the Conservation Units are not designed considering the aquatic landscapes but, instead, contours adjusted to vegetation patterns and mobility of large terrestrial fauna (eg Brandon et al., 2005). Few exceptions confirm the rule, such as the Jaru Biological Reserve in the State of Rondônia, Brazil, that was created to primarily protect the dry land area between the Madeira and Tapajós rivers and its endemism (ICMBio, 2010).

Another possibility would be to explore the relationship of people with nature in a more individualized way. In other words, lower the conservation steps on a planetary scale to conservation on the individual scale. Involve people in the context and viewpoint of their everyday universe as reference in an understandable language, bringing conservation issues to the field of individual accountability and, thus, hopefully eliciting the feeling of responsibility for the existing, threatened, and vanished species. (Soulé, 1988). Just as each one of us is responsible for what one consumes and, consequently, for the garbage it produces, each one of us should also be responsible for the polluted environments and for the species that disappear, ultimately.

Common sense believes in nature's healing power. This can be attested, even when analyzing different areas of human knowledge, from medicine to esotericism and from psychology to tourism. It is not uncommon to find slogans like "foods that heal", "stress-relieving trips," and "come and embrace cuddly wild animal's puppies", among others. In these examples, there is always a little recreational factor exploited by environmental conservation, although it is still extremely limited in terms of strategies.

We are very far from finding the ideal solutions - if they exist -, but we would be closer if the conservation actors were more daring and appealed to the playful, since the ludic knowingly seduce and attracts human attention.

\section{Conclusions}

From all that has been presented, in summary, we can conclude: 1) although freshwater actinopterygian teleostean fish represent the largest fraction of the diversity of vertebrate animals by far, both in the Neotropical Region as a whole and also in Brazil, they tend to be collectively ignored in the identification process of biodiversity hotspots and when establishing priority areas for conservation, together with other forms of conservation strategies; (2) medium to large-sized fish species (more than $15 \mathrm{~cm}$ in SL at adult size), due to their value for sustenance, sport, and commercial fishing, are much better known by the general public and also conservation agencies and organizations; 3) small-sized species (15 cm or less SL), although representing about $70 \%$ of the total diversity in species of the Neotropical Region, usually have their existence almost ignored by the same agents; 4) the absolute majority of species of medium to large size mainly inhabit the main rivers channels, having a great tolerance to the environmental variations and consequently very extensive geographic distributions; this is most probably the reason the medium and large-sized fish species only represent $58(19 \%)$ of the 311 threatened Brazilian continental fish species; 5) on the other hand, most probably because they inhabit mainly aquatic environments of smaller physical dimensions, such as ponds and marshes (temporary or not), or streams, and these areas are also more vulnerable to impacts than main channels of larger rivers and lakes, small-sized fish species adds up to 253 species (81\%) of the total endangered species; 6) finally, the main existing conservation policies and strategies, at least in Brazil, do not deal with continental fish and their environments.

Faced with this not very auspicious conservation scenario, we wondered as individuals, citizens, and conservation professionals what we could do for small-sized fish. We wanted to provoke this attitude! The first action that came to mind was to report the existence and importance of these fish and their environments at various levels: their collective biological, social, economic, and cultural importance. We started to gather and analyze data, some impressive when considering endangered species of fish as a whole. With $81 \%$ of the country's threatened freshwater fish being of less than $15 \mathrm{~cm} \mathrm{SL}$, it became clear that the problem of freshwater fish conservation, at least in Brazil, is the primary problem in small-sized fish conservation.

It seems likely that small-sized fish are not even remembered as conservation targets at any stage of political planning. In general, if fish are considered targets, they certainly are because they are seen as food and commercial resources, and yet, those "visible" species would most certainly be medium to large-sized fish but never the small-sized ones. Defining conservation targets necessarily involves a process of ranking conflicting interests, since it unavoidably involves ecological, economic, and social issues. Depending on the scale of the strategy, political and cultural issues are added, and the decision complexity increases.

In a historical analysis of the last hundred years, we will see the total convergence between two opposing situations: people living in direct and intense contact with nature, in which small-sized fish were probably part of the daily family life; or the almost complete disconnection of people from nature. Considering the countries of South America in the Neotropical region with territorial areas greater than $1,000,000$ $\mathrm{km}^{2}$ (Brazil, Argentina, Peru, Colombia and Bolivia), more than half the population is concentrated in large urban areas. South America has 43 urban agglomerations with more than one million inhabitants: 23 in Brazil; five in Colombia; four in Venezuela; three in Argentina; two in Ecuador and Bolivia, and one in Uruguay, Paraguay, Chile, and Peru, respectively. Collectively, these agglomerations contain more than 142 million inhabitants, adding up to more than $35 \%$ of the total of South American population. (https://pt.wikipedia.org/wiki/ List_of_the_Portugal_of_the_Brazil_of_the_South_America_with_ the_more_of_1_milh\%C3\% Of the inhabitants).

It is presumed, therefore, that in a relatively short time span, human societies started to have a pathetically restricted contact with nature. In relation to fish, some direct contact is still maintained, especially due to sport fishing and aquarium hobbies. However, sport fishing is practiced by a very small portion of the world population, and the 
aquarist market is increasingly based on non-native or already highly genetically manipulated species (Magalhães \& Jacobi, 2013b).

In this context, the problem of the conservation of small-sized freshwater fish species permeates tangible and intangible components. While on the one hand, it can be reasonably easy to carry out command and control measures to minimize, for example, the arrival of unwanted effluents into water bodies, provided there are political and economic interests as a backdrop; on the other hand, it is practically impossible to make people interested in small-sized fish, as they are ignored most of the time by the majority of people, including those belonging to the militant conservationist wing itself. Therefore, if there is no way to put this issue in the planning process of governmental policies for the environment, very little will be possible to do in favor of small-sized fish.

\section{Acknowledgements}

The following persons and institutions have aided this work in a variety of ways. Matheus Volcán, of the Pró-Pampa Institute, Michael Goulding, of the Wildlife Conservation Society (WCS), and Sergio Antoninni, gave us permission to use their photos. Fernanda Brando and Mário de Vivo, both of USP, and Rafael Loyola, of Universidade Federal de Goiás (UFG) read our manuscript and offered valuable criticism and suggestions. André Esguícero, a Post-Doctoral student at USP, was extremely helpful in the process of checking fish species adult sizes, both utilizing CCLOFSCCA and FISHBASE. Michael James Stablein, of the University of Illinois Urbana-Champaign, reviewed our usage of the English language. The Programa de Pós-Graduação em Biologia Comparada of FFCLRP (USP) provided financial support to RMCC for necessary work travels during the making of this article.

\section{Author Contributions}

Ricardo M. C. Castro: Contribution to the concept and design of the study, data collection, data analysis and interpretation and the manuscript preparation.

Carla N. M. Polaz: Contribution to the concept and design of the study, data collection, data analysis and interpretation and the manuscript preparation.

\section{Conflicts of Interest}

The authors declare that they have no conflict of interest related to the publication of this manuscript.

\section{Ethics}

Both co-authors have complied with the guidelines established by the ethics committees of their respective research institutions. No studies involving human beings and/or clinical trials were performed in the study here in question.

\section{Data Availability}

All the data analyzed in this study are available to public in the form of scientific publications or open access official scientific sites.

\section{References}

ABELL, R., THIEME, M., RICKETTS, T. H., OLWERO, N., NG, R., PETRY, P., DINERSTEIN, E., REVENGA, C. \& HOEKSTRA, J. 2011. Concordance of freshwater and terrestrial biodiversity. Conservation Letters 4:127-136.

ALBERT, J.S. \& REIS, R.E. 2011. Historical Biogeography of Neotropical Freshwater Fishes. 1 ed. University of California Press, Berkeley/Los Angeles/London.

ALBERT, J.S., BART, H.L. JR \& REIS, R.E. 2011. Species richness and cladal diversity. In Historical biogeography of neotropical freshwater fishes (J.S. Albert \& R.E. Reis, eds.). Berkeley and Los Angeles, University of California Press, pp. 89-104.

APONE, F., OLIVEIRA, A.K. DE \& GARAVELLO, J.C. 2008. Composição da ictiofauna do rio Quilombo, tributário do rio Mogi-Guaçu, bacia do alto rio Paraná, sudeste do Brasil. Biota Neotrop. 8(1):93-107. http://www. biotaneotropica.org.br/v8n1/pt/fullpaper?bn02208012008+pt (último acesso em: 17/01/2018)

BARLOW, J., FRANÇA F., GARDNER, T.A., HICKS, C.C., LENNOX, G.D., BERENGUE, E., CASTELLO, L., ECONOMO, E.P., FERREIRA, J., GUÉNARD, B., LEAL, C.G., ISAAC, V., LEES, A.C., PARR, C.L., WILSON, S.K., YOUNG, P.J., GRAHAM, N.A.J. 2018. The future of hyperdiverse tropical ecosystems. Nature 559:517-526 https:/doi. org/10.1038/s41586-018-0301-1.

BARTHEM, R.B., GOULDING, M., LEITE, R.G., CAÑAS, C., FORSBERG, B., VENTICINQUE, E., MERCADO, A. 2017. Goliath catfish spawning in the far western Amazon confirmed by the distribution of mature adults, drifting larvae and migrating juveniles. Nature Scientific Reports 7:41784. https://doi.org/10.1038/srep41784

BRANDON, K., FONSECA, G.A.B., RYLANDS, A.B. \& SILVA, J.M.C. 2005. Conservação brasileira: desafios e oportunidades. Megadiversidade 1(1):1-7. https://www.conservation.org/global/brasil/publicacoes/Pages/ revista-megadiversidade.aspx

CALHOUN, A.J.K., MUSHET, D.M., BELL, K.P., BOIX, D., FITZSIMONS, J.A., ISSELIN-NONDEDEUG, F. 2017. Temporary wetlands: challenges and solutions to conserving a 'disappearing' ecosystem. Biol. Conserv. 211:3-11.

CASATTI, L., TERESA, F.B., GONÇALVES-SOUZA, T., BESSA, E., MANZOTTI, A.R., GONÇALVES, C.S., ZENI, J.O. 2012. From forests to cattail: how does the riparian zone influence stream fish? Neotrop. ichthyol. 10(1): 205-214. http://dx.doi.org/10.1590/S1679-62252012000100020

CASATTI, L., PÉREZ-MAYORGA, M.A., ROGÉRIO CARVALHO, F., LOURENÇO BREJÃO, G. \& DA COSTA, I.D. 2013. The stream fish fauna from the rio Machado basin, Rondônia State, Brazil. Check List 9(6):1496-1504.

CASTRO, R. M. C. \& L. CASATTI. 1997. The fish fauna from a small forest stream of the upper Paraná River Basin, southeastern Brazil. Ichthyol. Explor. Freshwaters 7: 337-352.

CASTRO, R.M.C. \& VARI, R.P. 2004. Detritivores of the South American fish family Prochilodontidae (Teleostei: Ostariophysi: Characiformes): a phylogenetic and revisionary study. Smithsonian Contributions to Zoology 622: 1-189.

CASTRO, R.M.C. 1999. Evolução da ictiofauna de riachos sul-americanos: padrões gerais e possíveis processos causais. Oecologia Bras. 6(1):139-155.

CASTRO, R.M.C., CASATTI, L., SANTOS, H.F., FERREIRA, K.M., RIBEIRO, A.C., BENINE, R.C., DARDIS, G.Z.P., MELO, A.L.A., STOPIGLIA, R., ABREU, T.X., BOCKMANN, F.A., CARVALHO, M., GIBRAN, F.Z. \& LIMA, F.C.T. 2003. Estrutura e composição da ictiofauna de riachos do rio Paranapanema, Sudeste e Sul do Brasil. Biota Neotrop. 3(1):1-31. http:// www.biotaneotropica.org.br/v3n1/pt/fullpaper?bn01703012003_1+pt (last accessed on $02 / 10 / 2017$ )

CASTRO, R.M.C., CASATTI, L., SANTOS, H.F., MELO, A.L.A., MARTINS, L.S.F., FERREIRA, K.M., GIBRAN, F.Z., BENINE, R.C., CARVALHO, M., RIBEIRO, A.C., ABREU, T.X., BOCKMANN, F.A., PELIÇÃO, G.Z., STOPIGLIA, R. \& LANGEANI, F. 2004. Estrutura e composição da ictiofauna de riachos da bacia do Rio Grande no estado de São Paulo, sudeste do Brasil. Biota Neotrop. 4(1):01-39. http://www.biotaneotropica.org.br/ $\mathrm{v} 4 \mathrm{n} 1 / \mathrm{pt} /$ fullpaper?bn01704012004_1+pt (last accessed on 02/10/2017) 
CASTRO, R.M.C., CASATTI, L., SANTOS, H.F., VARI, R.P., MELO, A.L.A., MARTINS, L.S.F., ABREU, T.X., BENINE, R.C., GIBRAN, F.Z., RIBEIRO, A.C., BOCKMANN, F.A., CARVALHO, M., PELIÇÃO, G.Z.P., FERREIRA, K.M., STOPIGLIA, R. \& AKAMA, A. 2005. Structure and composition of the stream ichthyofauna of four tributary rivers of the upper Rio Paraná basin, Brazil. Ichthyol. Explor. Freshwaters 16(3):193-214.

COSTA, W. J. E. M. 1995. Pearl killifishes. The Cynolebiatinae. Systematics and biogeography of a Neotropical annual fish subfamily (Cyprinodontiformes: Rivulidae). Neptune, Tropical Fish Hobbyist Publications, 128p.

COSTA, W.J.E.M. 2002. Peixes Anuais Brasileiros: Diversidade e Conservação. Editora da UFPR, Curitiba.

COSTA, W.J.E.M. 2009. Peixes aploqueilóides da Mata Atlântica Brasileira: história, diversidade e conservação. Série Livros 34, Museu Nacional, UFRJ, Rio de Janeiro.

ESGUÍCERO, A.L.H. \& ARCIFA, M.S. 2011. The fish fauna of the JacaréGuaçu River basin, Upper Paraná River basin. Biota Neotrop. 11(1):1-13. http://www.biotaneotropica.org.br/v11n1/pt/fullpaper?bn01811012011+en (last accessed on 09/04/2018)

FAGUNDES, D.C., LEAL, C.G., CARVALHO, D.R. de, JUNQUEIRA, N.T., LANGEANI, F. \& POMPEU, P. dos S. 2015. The stream fish fauna from three regions of the Upper Paraná River basin. Biota Neotrop. 15(2): 1-8 http://www.scielo.br/scielo.php?script=sci arttext\&pid $=$ S1676-06032015000200203 (last accessed on 03/05/2018)

GOLDMAN, C.R; KUMAGAI, M.; ROBARTS, R.D. 2012 (first published online). Climatic Change and Global Warming of Inland Waters: Impacts and Mitigation for Ecosystems and Societies. John Wiley \& Sons, Ltd. doi:10.1002/9781118470596.

INSTITUTO CHICO MENDES DE CONSERVAÇÃO DA BIODIVERSIDADE - ICMBio. 2010. Resumo Executivo do Plano de Manejo da Reserva Biológica do Jaru. Disponível em: http://www.icmbio.gov.br/portal/images/ stories/imgs-unidades-coservacao/Resumo\%20Executivo $\% 20-\% 20 \mathrm{RB} \% 20$ do\%20Jaru.pdf

INSTITUTO CHICO MENDES DE CONSERVAÇÃO DA BIODIVERSIDADE - ICMBio. 2018. Livro Vermelho da Fauna Brasileira Ameaçada de Extinção: Volume VI - Peixes / -- 1. ed. -- Brasília, DF: ICMBio/MMA, 2018.7 v.: il.. Disponível em: http://www.icmbio.gov.br/portal/component/content/ article $/ 10187$

LANGEANI, F., CASTRO, R.M.C., OYAKAWA, O.T., SHIBATTA, O.A., PAVANELLI, C.S. \& CASATTI, L. 2007. Diversidade da ictiofauna do Alto Rio Paraná: composição atual e perspectivas futuras. Biota Neotrop. 7(3): 1-18. http://www.biotaneotropica.org.br/v7n3/pt/ fullpaper?bn03407032007+pt (last accessed on 19/03/2018)

LOWE Mc-CONNELL, R.H. 1987. Ecological Studies in Tropical Fish Communities. Cambridge University Press, Cambridge.

LOWE Mc-CONNELL, R.H. 1999. Estudos Ecológicos em Comunidades de Peixes Tropicais. Editora da Universidade de São Paulo, São Paulo.

MACHADO, A.B.M.; DRUMMOND, G.M. PAGLIA, A. P. (eds). 2008. Livro vermelho da fauna brasileira ameaçada de extinção. 1.ed. Brasília, DF: MMA; Belo Horizonte, MG: Fundação Biodiversitas,. 2v. 1420 p.

MAGALHÃES, A.L.B. \& JACOBI, C.M. 2013a. Invasion risks posed by ornamental freshwater fish trade to southeastern Brazilian rivers. Neotropical Ichthyology 11: 433-441.

MAGALHÃES, A.L.B. \& JACOBI, C.M. 2013b. Biol Invasions 15:2157. https:// doi.org/10.1007/s10530-013-0443-x
MENEZES, N.A., WEITZMAN, S.H., OYAKAWA, O.T., LIMA, F.C.T., CASTRO, R.M.C. \& WEITZMAN, M.J. 2007. Peixes de água doce da Mata Atlântica: lista preliminar das espécies e comentários sobre conservação de peixes de água doce neotropicais. Museu de Zoologia, Universidade de São Paulo, São Paulo, 407p.

MORAES, A.S.; ESPINOZA, L.W. 2001. Captura e comercialização de iscas vivas em Corumbá, MS. Corumbá: Embrapa Pantanal, 37p. (Embrapa Pantanal. Boletim de Pesquisa, 21). http://www.infoteca.cnptia.embrapa. br/infoteca/handle/doc/807371

MYERS, N., MITTERMEIER, R.A., MITTERMEIER, C.G., FONSECA, G.A.B., KENT J. 2000. Biodiversity hotspots for conservation priorities. Nature 403:853-858.

PERES NETO, P.R.; BIZERRIL, C.R.S.F. \& IGLESIAS, R. 1994. An overview of some aspects of river ecology: a case study on fish assemblages distribution in a eastern Brazilian coastal river. pp. 265-279. In: Esteves, F.A. (ed.), Oecologia Brasiliensis. Vol 1: Estrutura, Funcionamento e Manejo de Ecossistemas Brasileiros. Universidade Federal do Rio de Janeiro, Rio de Janeiro.

Portaria MMA N ${ }^{\circ} 130$, de 27 de abril de 2018. Reconhece como passível de exploração, estudo ou pesquisa pela pesca as espécies Parancistrus nudiventris, Scobinancistrus aureatus, Scobinancistrus pariolispos, Leporacanthicus joselimai, Peckoltia compta, Peckoltia snethlageae e Teleocichla prionogenys. Publicado em D.O.U.: 27/04/2018 | Edição: $82 \mid$ Seção: 1 | Páginas: 107 e 108.

REIS, R.E., KULLANDER S.O. \& FERRARIS-JR, C.J. (eds). Check List of Freshwater Fishes of South and Central America. Edipucrs, Porto Alegre, 729 p.

REIS, R.E., ALBERT, J.S., DI DARIO, F., MINCARONE, M.M., PETRY, P., ROCHA, L.A. 2016. Fish biodiversity and conservation in South America. Journal of Fish Biology 89:12-47. doi:10.1111/jfb.13016

RIBEIRO, F.A.S. 2008. Panorama mundial do mercado de peixes ornamentais. http://www.panoramadaaquicultura.com.br/paginas/Revistas/108/ Ornamentais108.asp (last accessed on 06/06/2018)

RIBEIRO, F.A.S., CARVALHO JÚNIOR, J.R., FERNANDES, J.B.K. \& NAKAYAMA, L. Comércio Brasileiro de Peixes Ornamentais. Panorama da Aquicultura. 2008. https://www.researchgate.net/profile/ Jaime_Carvalho_Junior/publication/313904504_Comercio_Brasileiro_ de Peixes Ornamentais/links/58b4780daca2725b541c39df/ComercioBrasileiro-de-Peixes-Ornamentais.pdf?origin=publication_detail (last accessed on 06/06/2018)

SIQUEIRA, T., PADIAL, A.A. \& BINI L.M. 2009. Mudanças climáticas e seus efeitos sobre a biodiversidade: um panorama sobre as atividades de pesquisa. Megabiodiversidade. 5(1-2):17-26. https://www.conservation.org/global/ brasil/publicacoes/Pages/revista-megadiversidade.aspx

SOULÉ, M.E. Mind in the biosphere; mind of the biosphere. 1988. In: Wilson, E.O (Ed.). Biodiversity. National Academy Press, Washington, D.C., pp. 465-469.

STRAHLER, A.N. 1957. Quantitative analysis of watershed geomorphology. Trans. Amer. Geoph. Union 38:913-920.

VANNOTE, R.L., MINSHALL, G.W., CUMMINS, K.W., SEDELL, J.R. \& C.E. CUSHING. 1980. The river continuum concept. Canadian Journal of Fisheries and Aquatic Sciences, 37:130-137.

VOLCAN, M.V. \& LANÉS, L.E.K. 2018. Brazilian killifishes risk extinction. Science (Letters) 361. http://science.sciencemag.org 